\title{
CAMBRIDGE JOURNAL OF
}

POSTCOLONIAL LITERARY

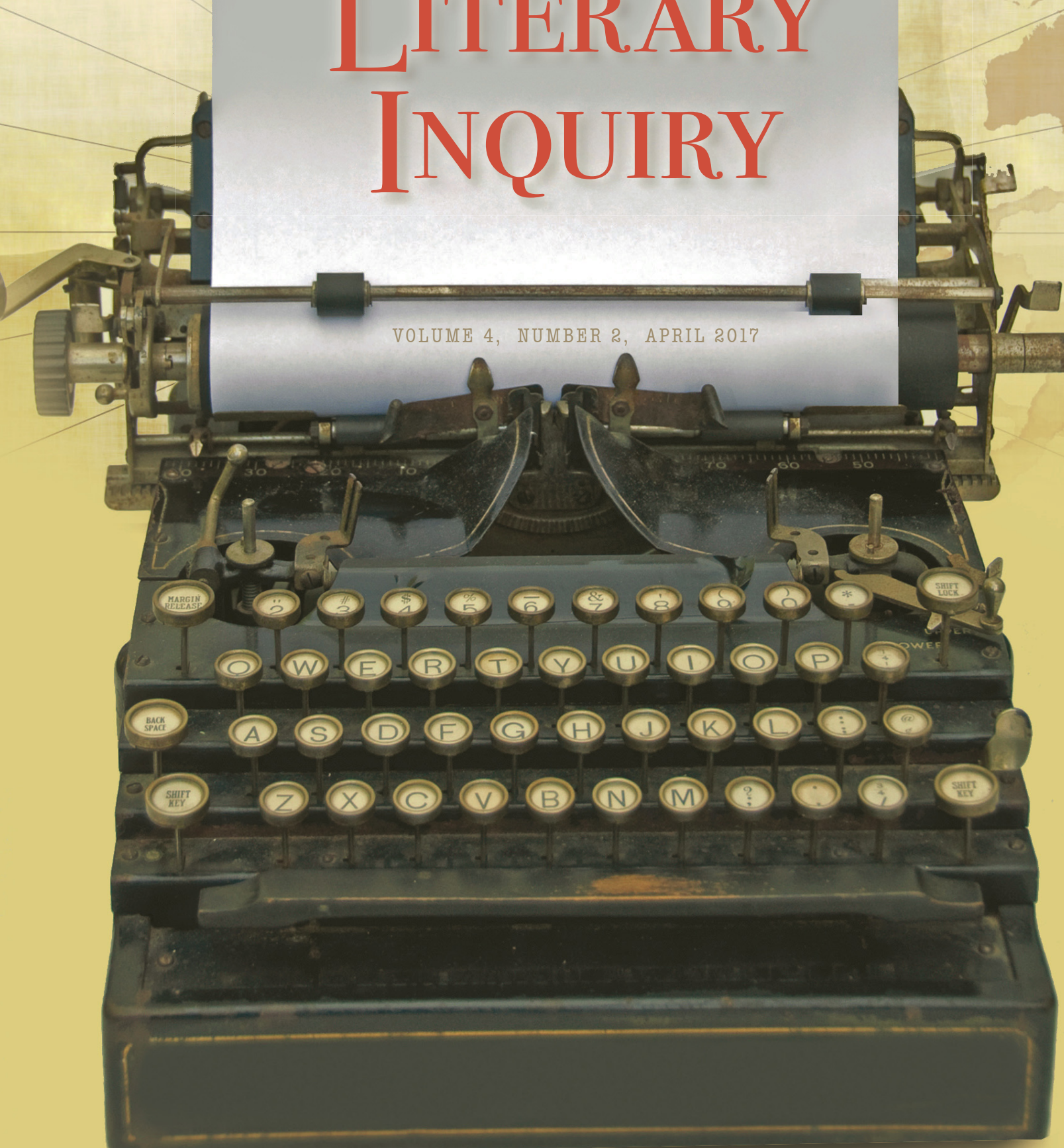




\section{Cambridge Journal of Postcolonial Literary Inquiry}

\section{Editorial Board}

\section{Editor}

Ato Quayson

University of Toronto, Canada

Associate Editors

Neil ten Kortenaar

University of Toronto, Canada

Debjani Ganguly

University of Virginia,

USA

\section{Editorial Board}

Muhsin Al-Musawi

Columbia University, USA

Ian Baucom

University of Virginia, USA

Joe Cleary

Yale University, USA

Daniel Coleman

McMaster University, Canada

Elizabeth DeLoughrey

UCLA, USA

Stefan Helgesson

Stockholm University, Sweden

Lene Johannessen

University of Bergen, Norway

\section{Reviews Editor}

Uzoma Esonwanne

University of Toronto, Canada

Editorial Assistant

Niyosha Keyzad

University of Toronto, Canada

\author{
Consultant Editors \\ Stephen Greenblatt \\ Harvard University, USA \\ Gayatri Spivak \\ Columbia University, USA \\ Derek Attridge \\ University of York, UK
}

\author{
Ananya Jahanara Kabir \\ King's College, London, UK \\ Neil Lazarus \\ University of Warwick, UK \\ Francoise Lionnet \\ UCLA, USA \\ Walter Mignolo \\ Duke University, USA
Ankhi Mukherjee
University of Oxford, UK
Julian Murphet
University of New South Wales,
Australia \\ Stephanie Newell \\ Yale University, USA
}

\author{
Tejumola Olaniyan \\ University of Wisconsin - Madison, USA \\ Rajeev Patke \\ National University of Singapore, \\ Singapore \\ Bhekizizwe Peterson \\ University of the Witwatersrand, \\ South Africa \\ Anjali Prabhu \\ Wellesley College, USA \\ Ira Raja \\ University of Delhi, India \\ Jahan Ramazani \\ University of Virginia, USA \\ Michelle Warren \\ Dartmouth College, USA
}

The Cambridge Journal of Postcolonial Literary Inquiry is a new peer-reviewed journal that aims to deepen our grasp of postcolonial literary history while enabling us to stay comprehensively informed of all critical developments in the field. The journal will provide a forum for publishing research covering the full spectrum of postcolonial critical readings and approaches, whether these center on established or lesser known postcolonial writers or draw upon fields such as Modernism, Medievalism, Shakespeare and Victorian Studies that have hitherto not been considered central to postcolonial literary studies, yet have generated some of the best insights on postcolonialism. The Journal aims to be critically robust, historically nuanced, and will put the broadly defined areas of literature and aesthetics at the center of postcolonial exploration and critique. Essays of up to 8000 words on any aspect of postcolonial literature, literary history and aesthetics should be sent to The Editor at pli@cambridge.org.

\section{Subscription Information:}

The Cambridge Journal of Postcolonial Literary Inquiry (ISSN: 2052-2614) is published three times a year in January, April, and September by Cambridge University Press, One Liberty Plaza, Floor 20, New York, NY 10006, USA.

The subscription price of Volume 4 (2017) including delivery by air where appropriate (but excluding VAT), is $\$ 518.00$ $(£ 323.00)$ for institutions print and online; $\$ 415.00$ ( $£ 258.00$ ) for institutions online only; $\$ 78.00$ ( $£ 48.00$ ) for individuals print only. For further information, visit www.cambridge.org/pli or contact Customer Services at Cambridge University Press e-mail subscriptions_newyork@cambridge.org (USA, Canada and Mexico) or journals@cambridge.org (outside of USA, Canada and Mexico).

\section{Advertising:}

To advertise in the journal email USAdSales@cambridge.org or telephone +1 (212) 3375053 in the USA, Canada and Mexico; email ad_sales@cambridge.org or telephone +44 (1223) 325083 in the rest of the world.

\section{Copyright and Permissions}

Copyright (C) Cambridge University Press 2017. All rights reserved. No part of this publication may be reproduced, in any form or by any means, electronic, photocopying, or otherwise, without permission in writing from Cambridge University Press. Policies, request forms and contacts are available at: www.cambridge.org/about-us/rights-permissions. Permission to copy (for users in the U.S.A.) is available from Copyright Clearance Center http://www.copyright.com, email: info@copyright.com.

For all other use: Permission should be sought from the Cambridge University Press. Full details may be found at: www. cambridge.org/about-us/rights-permissions.

Postmaster: Send address changes to Cambridge Journal of Postcolonial Literary Inquiry, Cambridge University Press, One Liberty Plaza, Floor 20, New York, NY 10006, USA. 


\title{
Cambridge Journal of Postcolonial Literary Inquiry
}

\author{
Special Issue: African Genre
}

volume 4 | number 2 | April 2017

151 Introduction: Genre in Africa

Tsitsi Jaji and Lily Saint

159 Counter-Fitting

Peter Hitchcock

176 Animating Genre in the Yorùbá Photoplay Series

Olubukola A. Gbadegesin

191 The Materiality of Genre: Analog and Digital Ghosts in Video Movies from Ghana

Carmela Garritano

207 What Is and Where Is Francophone African Popular Fiction? Pim Higginson

222 Thinking around Genre: The Moral Narrative and Femininity in Kenyan Popular Media

Dina Ligaga

237 African Science Fiction and the Planning Imagination

Matthew Eatough

258 Afterword: Genre Queries, African Studies

Moradewun Adejunmobi

Forum

265 "Yes, but ..." : On Reforming African Literary Scholarship Uzoma Esonwanne

271 From Post-Global to Post-Truth: African Literature beyond Commonsense

Pius Adesanmi 
280 Re-Narrating the Post-Global

Olakunle George

286 The Ethics of African Studies in the Age of Oga Politics: A Response to Tejumola Olaniyan's "African Literature in the Post-Global Age" Laura T. Murphy

296 An Intellectual History of African Literary Studies?

Taiwo Adetunji Osinubi

307 Africa in What Age: Post-Global or Post-Rwanda?

Kwaku Larbi Korang

323 Africa, Post-Global: A Reaffirmation

Tejumola Olaniyan

Explication de Texte

332 Teaching Mulk Raj Anand's Untouchable: Colonial Context, Nationalism, Caste

S. Shankar

Book Reviews

342 Laurent Dubreuil Empire of Language: Toward a Critique of (Post)colonial Expression

(Philip Dickinson)

343 Carrie Noland Voices of Negritude in Modernist Print: Aesthetic Subjectivity, Diaspora, and the Lyric Regime (Glyne Griffith) 